\title{
POTENSI SATASABANG SEBAGAI KAWASAN MINAPOLITAN DALAM ROADMAP SISTEM INOVASI DAERAH KABUPATEN LABUHANBATU DENGAN ANALISIS SWOT
}

\section{THE POTENTIAL OF SATASABANG AS A MINAPOLITAN AREA IN THE ROADMAP OF THE REGIONAL INNOVATION SYSTEM OF LABUHANBATU REGENCY WITH SWOT ANALYSIS}

\author{
Siti Masliyah Lubis ${ }^{1}$, Andjar Prasetyo ${ }^{2}$ \\ ${ }^{1}$ Author Address; sitimasliyahlubis@gmail.com
}

Dikirim 18 Juni 2021, Direvisi 12 Juni 2021, Disetujui 29 Juli 2021

\begin{abstract}
Abstrak: Tujuan penelitian untuk mengidentifikasi dan menganalisis potensi yang dapat dikembangkan di Satasabang sebagai kawasan minapolitan yang menjadi agenda dalam Roadmap SIDa Kabupaten Labuhanbatu tahun 2021-2026. Penelitian ini mendeskripsikan hasil data yang diperoleh secara kualitatif. Sumber data sekunder berasal dari perangkat daerah dan Badan Pusat Statistik Kabupaten Labuhanbatu. Data primer berupa wawancana dan observasi dengan instumen kuisioner. Lokasi penelitian di Desa/Kelurahan Sei Sakat, Sei Tawar, Sei Sanggul dan Sei Berombang, Kecamatan Panai Hilir Kabupaten Labuhanbatu. Pengumpulan data dengan metode survey, observasi dan wawancara terbuka terhadap responden. Waktu penelitian mulai bulan Januari sampai dengan Mei 2021. Analisis data menggunakan SWOT. Hasil identifikasi menunjukan adanya potensi hasil tangkapan yang melimpah, namun membutuhkan dukungan kelembagaan, infrastruktur, peningkatan kapasitas dan kemampuan nelayan. Hasil analisis dengan pengukuran SWOT diperoleh skor 61 poin untuk total kekuatan dan kesempatan, sedangkan total kelemahan dan tantangan mencapai 71 poin, Upaya pengembangan melalui Roadmap SIDa terhadap Kawasan Satasabang menjadi Kawasan Minapolitan.
\end{abstract}

Kata kunci: Kawasan minapolitan, Sistem Inovasi Daerah, SWOT

\begin{abstract}
The purpose of the research is to identify and analyze the potential that can be developed in Satasabang as a minapolitan area which is on the agenda in the Labuhanbatu Regency RIS Roadmap for 2021-2026. This study describes the results of the data obtained qualitatively. Secondary data sources come from the regional apparatus and the Central Statistics Agency of Labuhanbatu Regency. Primary data in the form of interviews and observations with questionnaire instruments. The research location is in the villages of Sei Sakat, Sei Tawar, Sei Sanggul and Sei Berombang, Panai Hilir District, Labuhanbatu Regency. Data collection by survey method, observation and open interview to respondents. The research time is from January to May 2021. Data analysis uses SWOT. The identification results show the potential for abundant catches, but requires institutional support, infrastructure, capacity building and fishermen's capabilities. The results of the analysis using the SWOT measurement obtained a score of 61 points for the total strengths and opportunities, while the total weaknesses and challenges reached 71 points. Development efforts through the SIDa Roadmap of the Satasabang Area into a Minapolitan Area.
\end{abstract}

Keywords: Minapolitan area, Regional Innovation System, SWOT

\section{PENDAHULUAN}

Kabupaten Labuhanbatu terbagi dalam wilayah administrasi kecamatan terdiri dari Panai Hilir, Bilah Hulu, Pangkatan, Bilah Barat, Bilah Hilir, Panai Hulu, Panai Tengah, Rantau Selatan dan Rantau Utara. Kecamatan Panai Hilir menempati area seluas 342,03 $\mathrm{Km}^{2}$ yang terdiri dari tujuh desa dan satu kelurahan. Kecamatan Panai Hilir adalah wilayah yang berbatasan langsung dengan selat Malaka, sehingga kaya akan hasil lautnya. Badan Pusat Statistik (BPS) pada tahun 2020 merilis jumlah nelayan di Kabupaten Labuhanbatu mencapai 6.384 orang, sebanyak 4.444 orang atau $69,61 \%$ diantaranya terdapat di Kecamatan Panai Hilir. Sumber daya alam di sektor perikanan dan kelautan di Kecamatan Panai Hilir melimpah. Jumlah armada tangkap ikan (kapal dan boat) mencapai 1.231 unit dan hasil tangkapan 
laut mencapai 3.545,81 ton untuk tahun 2020. Beberapa jenis perikanan laut yang ditangkap oleh nelayan Kecamatan Panai Hilir meliputi ikan, teri, udang, kerang, cumi, sotong, kepiting dan rajungan. Potensi sumberdaya perikanan tangkap ini perlu dimanfaatkan dengan baik sehingga dapat menggerakkan perekonomian daerah dengan menempatkan Kawasan tersebut dalam Roadmap Sistem Inovasi Daerah (SIDa) Kabupaten Labuhanbatu menjadi Kawasan Minapolitan. Kecamatan Panai Hilir direncanakan di tiga desa dan satu kelurahan meliputi Desa Sei Sanggul, Desa Sei Sakat, Desa Sei Tawar, Kelurahan Sei Berombang menjadi Kawasan Minapolitan. Kawasan minapolitan pada beberapa wilayah di Indonesia telah dikembangkan dan mampu memberikan kontribusi terhadap peningkatan kesejahteraan masyarakatnya. Hal ini ditunjukan setidaknya dalam satu dasa warsa melalui beberapa artikel ilmiah misalnya (Erlina \& Manadiyanto, 2012) yang melakukan penelitian di Kabupaten Pamekasan terhadap potensi minapolitan garam, (Hikmah \& Purnomo, 2012) bahkan meneliti di Kabupaten Bogor, Banjar, Sleman, Pangkep, Lamongan, Bintan, Waingapu, Waingapu, Kota Jayapura tentang minapolitan berbasis budidaya perikanan, Minapolitan Ketapang Lampung yang diteliti oleh (Cahya \& Mareza, 2013) juga menguatkan adanya penerapan Kawasan minapolitan, (Febriyanti, 2013) meneliti di Kabupaten Boyolali dengan penerapan minapolitan di Kampung Lele, penerapan budidaya laut dengan minapolitan di Kabupaten Lampung Timur yang dilakukan oleh (Ambasari et al., 2013), (Adhihapsari et al., 2014) yang melakukan penelitian minapolitan di Kabupaten Blitar, selanjutnya oleh (Edrus, 2015) dengan lokasi minapolitan di Kota Bengkulu, (Agustine, 2016) meneliti di Desa Kemangi, Kecamatan Bungah, Kabupaten Gresik dengan pendekatan strategi perencanaan, (Maulana \& Nurhadi, 2016) meneliti minapolitan di Kabupaten Kulonprogo dengan strategi peningkatan daya saing.
(Dewi \& Asparini, 2018) meneliti di Kabupaten Bogor, mengawinkan minapolitan dengan desa wisata, (D et al., 2018) dengan lokus penelitian di Kabupaten Majene, sedangkan (Zain \& Febrianty, 2018) berlokus di Kabupaten Banjar, kemudian (Surbakti et al., 2019) di Kabupaten Morowali Utara, selanjutnya Kabupaten Minahasa sebagai lokus penelitian yang dilakukan oleh (Kuhu et al., 2019), kemudian (Karepesina et al., 2019) meneliti di Kabupaten Seram, (Onibala et al., 2019) menjadikan Kota Bitung dalam penelitian minapolitan, (Shara, 2019) yang berlokasi di Kabupaten Jembrana dan (Kurniati et al., 2020) meneliti minapolitan di Kabupaten Bantul serta Kabupaten Sumbawa Besar menjadi lokus penelitian minapolitan oleh (Nursan et al., 2020).

Kecamatan Panai Hilir yang memiliki sumberdaya perikanan melalui Pemerintah Kabupaten Labuhanbatu diprogramkan menjadi salah satu agenda kebijakan yang tertuang dalam Rencana Pembangunan Jangka Pendek Daerah (RPJMD) tahun 2021-2026. Implementasinya dilakukan melalui Roadmap SIDa Kabupaten Labuhanbatu tahun 2021-2026. Roadmap SIDa digunakan sebagai salah satu upaya karena dalam pelaksanaannya melibatkan berbagai stakeholder yang ada di wilayah SIDa secara terintegrasi melalui pendekatan inovasi. Stakeholder yang terlibat diberikan ruang untuk berpartisipasi aktif menuangkan berbagai inovasi melalui Roadmap SIDa. SIDa di beberapa daerah telah menjadi perhatian ilmiah dengan munculnya beberapa penelitian yang memberikan dorongan terhadap suatu wilayah dalam meningkatkan produk unggulannya secara terintegrasi. (Handayani et al., 2012) misalnya melakukan penelitian SIDa di Kota Semarang, (Narutomo, 2014) yang menyatakan SIDa sebagai exit strategy, (Ismiatun, 2015) yang meneliti SIDa terhadap daya saing daerah, kemudian (Risandewi, 2017) memberikan ukuran tingkat kematangan SIDa serta (Suresti, Amna Dinata, Uyung Gatot S. Hellyward, 
James Wati, 2017) meneliti bidang peternakan dalam koridor SIDa. Rujukan tentang implementasi SIDa terhadap produk unggulan daerah ini pun kemudian menjadi agenda yang akan dicapai dan dituangkan dalam Roadmap SIDa.

Namun dalam pengembangan Kawasan minapolitan di Kecamatan Panai Hilir membutuhkan studi awal sebagai dasar yang dapat direalisasikan dalam Roadmap SIDa Kabupaten Labuhanbatu tahun 20212026. Oleh karena itu penelitian ini berusaha untuk membahas bagaimana potensi wilayah Satasabang dalam pengembangan minapolitan yang diintervensi melalui Roadmap SIDa tahun 2021-2026. Tujuan penelitian ini untuk mengidentifikasi hasil perikanan yang diperoleh nelayan di lokus penelitian, menganalisis komoditas unggulan yang dapat dikembangkan di Satasabang. Satasabang merupakan akronim dari empat wilayah yang menjadi Kawasan minapolitan yaitu Desa Sei Sakat, Desa Sei Tawar, Desa Sei Sanggul dan Kelurahan Sei Berombang. Satasabang sebagai rintisan kawasan minapolitan, tujuan berikutnya adalah menyampaikan opsi strategi Kawasan Satasabang sebagai Kawasan yang menjadi agenda dalam Roadmap SIDa Kabupaten Labuhanbatu tahun 2021-2026.

\section{LANDASAN TEORI}

Minapolitan terdiri dari kata mina dan kata politan (polis). Mina berarti ikan dan Politan berarti kota, sehingga Minapolitan dapat diartikan sebagai kota perikanan atau kota di daerah lahan perikanan. Peraturan Menteri Kelautan dan Perikanan Nomor PER.12/MEN/2010 tentang Minapolitan, definisi dari Minapolitan adalah konsepsi pembangunan ekonomi kelautan dan perikanan berbasis kawasan berdasarkan prinsip-prinsip terintegrasi, efisiensi, berkualitas dan percepatan. Kawasan Minapolitan adalah suatu bagian wilayah yang mempunyai fungsi utama ekonomi yang terdiri dari sentra produksi, pengolahan, pemasaran komoditas perikanan, pelayanan jasa, dan/atau kegiatan pendukung lainnya. (Keputusan Menteri Perikanan dan Kelautan No. 18 Tahun 2011 Tentang Pedoman Umum Minapolitan). Dalam persepsi regulasi minapolitan pada tingkat daerah di Indonesia diatur dalam setidaknya beberapa peraturan, mulai dengan Undang-Undang Nomor 31 Tahun 2004 tentang Perikanan sebagaimana telah diubah dengan UndangUndang Nomor 45 Tahun 2009; UndangUndang Nomor 16 Tahun 2006 tentang Sistem Penyuluhan Pertanian, Perikanan dan Kehutanan; Undang-undang Nomor 26 Tahun 2007 tentang Penataan Ruang; Undang-Undang Nomor 27 Tahun 2007 tentang Pengelolaan Wilayah Pesisir dan Pulau-Pulau Kecil; Undang-Undang nomor 17 Tahun 2007 tentang Perencanaan Pembangunan Jangka Panjang Tahun 20052025; Peraturan Pemerintah Nomor 54 Tahun 2002 tentang Usaha Perikanan; Peraturan Menteri Kelautan dan Perikanan Nomor PER.06/MEN/2010 tentang Rencana Strategis Kementerian Kelautan dan Perikanan; Peraturan Menteri Kelautan dan Perikanan Nomor PER.18/MEN/2012 tentang Pedoman Penyusunan Rencana Induk Pengembangan Kawasan Minapolitan; Peraturan Menteri Kelautan dan Perikanan Nomor PER.12/MEN/2010 tentang Minapolitan; Peraturan Menteri Kelautan dan Perikanan Nomor 39/2011 tentang Penetapan Kawasan Minapolitan; Keputusan Menteri Perikanan dan Kelautan No. 18 Tahun 2011 Tentang Pedoman Umum Minapolitan. Meskipun demikian dalam PerMen Kelautan dan Perikanan Nomor 39/2011 tentang Penetapan Kawasan Minapolitan Kabupaten Labuhanbatu tidak termasuk dalam Kawasan Minapolitan.

Minapolitan dilaksanakan dengan tujuan: 1) Meningkatkan produksi, produktivitas, dan kualitas produk kelautan dan perikanan; 2) Meningkatkan pendapatan nelayan, pembudidaya ikan, dan pengolah ikan yang adil dan merata; 3) Mengembangkan kawasan minapolitan sebagai pusat 
pertumbuhan ekonomi di daerah. Kawasan minapolitan sebaiknya mempunyai karakteristik sebagai berikut:

1) Suatu kawasan ekonomi yang terdiri atas sentra produksi, pengolahan, dan/atau pemasaran dan kegiatan usaha lainnya, seperti jasa dan perdagangan;

2) Mempunyai sarana dan prasarana sebagai pendukung aktivitas ekonomi;

3) Menampung dan mempekerjakan sumberdaya manusia di dalam kawasan dan daerah sekitarnya; dan

4) Mempunyai dampak positif terhadap perekonomian di daerah sekitarnya.

Berdasarkan Keputusan Menteri Perikanan dan Kelautan No. 18 Tahun 2011 Tentang Pedoman Umum Minapolitan, suatu kawasan dapat ditetapkan sebagai kawasan minapolitan apabila memenuhi persyaratan Kesesuaian dengan Renca Strategis, Rencana Tata Ruang Wilayah (RTRW) dan/atau Rencana Zonasi Pengelolaan Wilayah Pesisir dan PulauPulau Kecil (RZWP-3-K) kabupaten/kota, serta Rencana Pengembangan Investasi Jangka Menengah Daerah (RPIJMD) yang telah ditetapkan; Memiliki komoditas unggulan di bidang kelautan dan perikanan dengan nilai ekonomi tinggi, meliputi: a)Keberadaan komoditas unggulan, yaitu melimpah atau dapat dibudidayakan dengan baik dengan prospek pengembangan tinggi di masa depan; b)Nilai perdangan komoditas tinggi dengan pertimbangan memiliki pasar: lokal, nasional atau internasional; volume atau kemampuan produksi tinggi: dapat atau berpotensi memenuhi permintaan pasar; tingkat produktivitas tinggi: kemampuan pemanfaatan teknologi untuk mencapai tingkat produktivitas tinggi atau dapat dikembangkan sehingga secara ekonomi menguntungkan; jumlah pelaku utama/usaha perikanan relatif besar atau sebagian besar penduduk setempat bekerja di kawasan tersebut; mempunyai keunggulan komparatif: mempunyai nilai lebih karena keberadaan komoditas, iklim,
SDM, dan ongkos produksi murah; dan mempunyai keunggulan kompetitif: produk berkualitas dan sistem pemasaran efektif.

\section{METODOLOGI}

Penelitian ini mendeskripsikan hasil data yang diperoleh yang dianalisis secara kualitatif. Sumber data yang digunakan berasal dari data sekunder dan data primer, data sekunder mengacu pada publikasi perangkat daerah dan BPS Kabupaten Labuhanbatu. Pendekatan deskriptif kualitatif menjadi metode dalam penelitian ini mengacu pada (Lune, H. \& Berg, 2017) yang menyebutkan bahwa pendekatan kualitatif sangat ketat, namun reflektif atau interpretative untuk penelitian empiris, Keterlibatan aktif individu secara tradisional dikenal sebagai subjek sebagai peserta dan kontributor dalam penelitian, Integrasi beberapa hasil praktis yang terkait dengan kehidupan nyata para peserta dalam penelitian ini dan merupakan langkah spiral, yang masing-masing terdiri dari beberapa jenis perencanaan, tindakan, dan evaluasi. Lokasi penelitian dilakukan di Desa Sei Sakat, Desa Sei Tawar, Desa Sei Sanggul dan Kelurahan Sei Berombang, ke empat lokus ini berada dalam Kecamatan Panai Hilir Kab. Labuhanbatu. Pengumpulan data dilakukan dengan metode survey, observasi dan wawancara terbuka terhadap responden di lokus kajian dengan distribusi jumlah responden terdiri dari Desa Sei Sakat sebanyak satu responden, Desa Sei Tawar sebanyak dua responden, Desa Sei Sanggul sebanyak enam responden dan Kelurahan Sei Berombang sebanyak 10 responden. Jumlah responden yang berbeda ini menyesuaikan dengan partisipasi dari responden terhadap instumen kuisioner yang dibagikan. Waktu penelitian dilakukan mulai bulan Januari sampai dengan Mei 2021. Analisis data yang digunakan adalah analisis SWOT dengan tahapan mengidentifikasi hasil survey kemudian diintepretasikan dalam kekuatan, kelemahan, kesempatan dan tantangan. SWOT digunakan sebagai analisis dalam 
penelitian ini merujuk pada (Benzaghta et al., 2021) yang menyebutkan bahwa SWOT adalah alat yang mudah digunakan pada tahap evaluasi untuk mendapatkan ide awal tentang kemungkinan konsekuensi di masa depan. Analisis SWOT adalah metode analisis sederhana yang dapat memberikan interpretasi realistis tentang kekuatan dan kelemahan suatu bisnis.

\section{HASIL DAN PEMBAHASAN}

Hasil survey yang telah dilakukan dapat dideskripsikan bahwa 19 responden nelayan yang ada di lokus kajian berada diantara pada usia 28 tahun sampai 68 tahun, dari sisi Pendidikan, sebanyak delapan responden tidak sekolah, jenjang SD sebanyak lima responden, SMA lima responden dan Tidak tamat satu responden. Dalam melaut, jenis kapal yang digunakan nelayan sebanyak 11 nelayan atau 57,9\% jenis Perahu Motor Tempel, Kapal Motor sebanyak 2 atau 10,5\%, Perahu Tanpa Motor dan Sampan masing-masing satu nelayan atau dapat disebutkan 5,3\%, sisanya sebanyak empat nelayan atau 21,1\% tidak menjelaskan jenis kapal yang digunakan. Sementara itu untuk ukuran yang digunakan didominasi ukuran sebesar $<5$ GT sebanyak 13 nelayan atau 68,4\%, sedangkan yang menggunakan ukuran kapal antara 5-10 GT sebanyak empat nelayan atau $21,1 \%$, sisanya tidak memberikan jawaban sebanyak dua nelayan atau sebesar $10,5 \%$. Dengan menggunakan jenis kapal dan ukuran kapal tersebut, nelayan yang menjadi responden mampu menghasilkan tangkapan sekali melaut mencapai 670 kilogram dengan jenis tangkapan didominasi ikan jenis gembung yang mencapai volume hasil tangkap sebanyak 450 kilogram, sisanya berupa ikan tangkapan lainnya yang dapat dilihat pada gambar berikut

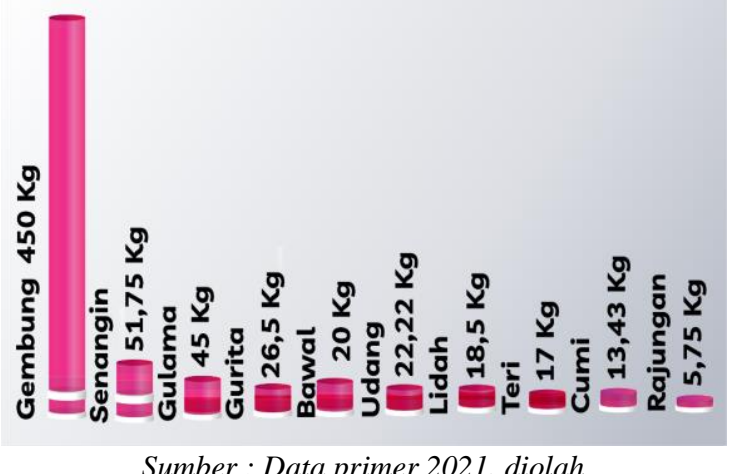

Gambar 1. Rata-rata Hasil Tangkapan

Responden dalam sekali melaut. Letak geografi kawasan yang strategis dan secara alami memenuhi persyaratan untuk pengembangan produk unggulan kelautan dan perikanan, meliputi: lokasi kawasan strategis dengan indikator jarak dan sistem transportasi; dan mempunyai akses terhadap jaringan pengadaan bahan baku, pengolahan, dan pemasaran (mata rantai pemasokan - supply chains). kawasan yang secara alami cocok untuk usaha perikanan yang ditunjukan dengan kaya SDA, subur, dan air melimpah; tempat pendaratan ikan (tangkap); dan dekat dengan fishing ground (tangkap). Dalam gambar 1 telah diinformasikan bahwa hasil jumlah tangkapan yang bervariasi memberikan indikasi potensi dari kondisi geografis, potensi produk unggulan yang berasal dari hasil tangkapan nelayan.

Selanjutnya kemampuan dalam melaut yang dilakukan responden dari pengalaman menjadi nelayan tangkap rata-rata sudah dilakukan selama 22 tahun, sedangkan Lama waktu yang dibutuhkan nelayan untuk melaut (dihitung dari berangkat pagi hingga pulang) rata-rata 10 jam 26 menit. Kemudian dari jumlah trip nelayan melaut rata-rata sebanyak 19 kali dalam satu bulan. Dalam hasil tangkapan responden menggunakan sistem pembayaran dengan Anak Buah Kapal (ABK) dengan sistem bagi hasil berkisar antara $70 \%-75 \%$ untuk pemilik dan 25\%-30\% untuk ABK yang diperoleh setelah melakukan penjualan hasil tangkapan tersebut. hasil tangkapan dominan dijual di luar tempat pelelangan ikan (TPI). Respon selanjutnya ditemukan 
kondisi bahwa nelayan tidak pernah mendapatkan dan mengikuti pelatihan baik yang diselenggarakan pemerintah maupun lembaga non pemerintah meskipun nelayan sangat membutuhkan pelatihan maupun penyuluhan untuk meningkatkan Sumber Daya Manusia (SDM), sehingga jenis produk olahan nelayan dapat bervariasi dan berkembang. Hal ini juga dapat terlihat rata-rata nelayan menjual hasil tangkapan ikan berbentuk ikan segar.

Proses pengembangan Kawasan Minapolitan diindikasikan dengan adanya unit produksi, pengolahan, pemasaran dan jaringan usaha yang aktif berproduksi. Dari hasil identifikasi tersebut terdapat Potensi dan Unit Produksi, pengolahan dan Pemasaran, yang dapat dilihat pada tabel berikut :

Tabel 1. Identifikasi Potensi dan kendala Unit Produksi, pengolahan dan Pemasaran

\begin{tabular}{|c|c|c|c|}
\hline No & Variabel & Potensi & Kendala \\
\hline 1. & $\begin{array}{l}\text { Unit } \\
\text { Produksi }\end{array}$ & & $\begin{array}{l}\text { Perahu/kapal yang } \\
\text { beroperasi } \\
\text { melakukan } \\
\text { penangkapan ikan } \\
\text { masih bersifat } \\
\text { tradisional, dengan } \\
\text { persentase: } \\
\text { - Perahu <5 GT } \\
\quad 68,4 \% \\
\text { - Perahu 5-10 GT } \\
21,1 \%\end{array}$ \\
\hline 2. & $\begin{array}{l}\text { Unit } \\
\text { Pengolahan }\end{array}$ & $\begin{array}{l}\text { Alat } \\
\text { pengeringan } \\
\text { ikan (on } \\
\text { process) di } \\
\text { Kel. Sei } \\
\text { Berombang }\end{array}$ & $\begin{array}{l}\text { - Modal untuk } \\
\text { pengolah produk } \\
\text { olahan ikan } \\
\text { belum mencukupi } \\
\text { - Mesin dan } \\
\text { teknologi dalam } \\
\text { proses produksi } \\
\text { belum tersedia } \\
\text { - Kelompok Usaha } \\
\text { Bersama (KUB) } \\
\text { pengolahan ikan } \\
\text { tidak tersedia }\end{array}$ \\
\hline 3. & $\begin{array}{l}\text { Unit } \\
\text { Pemasaran }\end{array}$ & - & $\begin{array}{l}\text { - Tempat } \\
\text { Pelelangan Ikan } \\
\text { (TPI) tidak } \\
\text { tersedia } \\
\text { - Terdapat } \\
\text { kesulitan dalam } \\
\text { pemasaran hasil } \\
\text { tangkapan: } \\
\text { kualitas rendah, } \\
\text { harga rendah dan } \\
\text { produk melimpah }\end{array}$ \\
\hline
\end{tabular}

\begin{tabular}{lll}
\hline 4. $\begin{array}{l}\text { Industri } \\
\text { Pendukung }\end{array}$ & - Toko distributor \\
& penyedia alat \\
& tangkap di \\
& pelabuhan \\
& terbatas. \\
& - Perusahaan \\
& pembekuan ikan \\
& yang ada belum \\
& memadai \\
\hline
\end{tabular}

Sumber : Data Primer 2021, diolah

Idealnya mengolah, memasarkan yang terkonsentrasi di suatu lokasi dan mempunyai mata rantai produksi pengolahan, pemasaran yang saling terkait, meliputi: Sistem dan mata rantai produksi perikanan budidaya ditandai dengan keberadaan sejumlah unit produksi ikan budidaya yang aktif berproduksi dan terkonsentrasi di sentra produksi atau mata Rantai Produksi. Pada rantai produksi ditunjukan dengan adanya keberadaan sarana/lahan produksi: kolam dan tambak yang cukup luas; fasilitas pengairan yang baik dan mencukupi atau potensi pengairan yang mungkin dikembangkan; ketersediaan benih berkualitas tinggi atau kemungkinan pengadaan benih dengan harga murah; ketersediaan pakan dan obat-obatan yang murah; telah diterapkan sistem budidaya yang baik sehingga tingkat produksinya cukup tinggi dan berkualitas; keterlibatan pembudidaya dan para pekerja setempat; sistem distribusi dan pemasaran telah berjalan dengan baik atau dapat segera dikembangkan lebih baik; dan sentra produksi mempunyai skala usaha layak secara ekonomi dan multiplier effect terhadap perekonomian di daerah sekitarnya. Hal ini menjadi kebutuhan yang perlu dipersiapkan mengingat hasil yang diperoleh. Sarana dan Prasarana Pendukung menjadi identifikasi berikutnya dengan parameter potensi dan kendala. Adapun hasil identifikasi seperti dalam tabel berikut : 
Tabel 2. Hasil Identifikasi Potensi dan Kendala Sarana dan Prasarana Pendukung

\begin{tabular}{|c|c|c|c|}
\hline $\begin{array}{l}\mathrm{N} \\
\mathrm{O}\end{array}$ & Variabel & Potensi & Kendala \\
\hline 1 & Permodalan & $\begin{array}{l}\text { Misal:banyak } \\
\text { nya pengepul } \\
\text { sebagai pihak } \\
\text { penjual yang } \\
\text { menjadi } \\
\text { pemodal para } \\
\text { nelayan yang } \\
\text { akan } \\
\text { melakukan } \\
\text { penangkapan } \\
\text { ikan }\end{array}$ & $\begin{array}{l}\text { Kurangnya } \\
\text { kerjasama dengan } \\
\text { pihak lembaga } \\
\text { keuangan seperti } \\
\text { bank agar } \\
\text { memeberikan } \\
\text { bantuan } \\
\text { permodalan } \\
\text { dengan syarat dan } \\
\text { sistem agunan } \\
\text { yang khusus } \\
\text { dengan bunga } \\
\text { yang rendah } \\
\text { kepada nelayan } \\
\text { guna memenuhi } \\
\text { kebutuhan modal } \\
\text { nelayan. }\end{array}$ \\
\hline 2 & $\begin{array}{l}\text { Sarana dan } \\
\text { Prasarana }\end{array}$ & $\begin{array}{l}\text { Terdapat } \\
\text { bengkel kapal } \\
\text { tetapi belum } \\
\text { memadaidan } \\
\text { tidak tersebar }\end{array}$ & $\begin{array}{l}\text { - Belum } \\
\text { terbangunnya } \\
\text { TPI, TPI Sei } \\
\text { Sanggul tidak } \\
\text { berfungsi } \\
\text { dengan baik } \\
\text { - Dermaga labuh } \\
\text { kapal kurang } \\
\text { memadai } \\
\text { - Stasiun } \\
\text { pengisian bahan } \\
\text { bakar nelayan } \\
\text { kurang } \\
\text { memadai (sei } \\
\text { sanggul), untuk } \\
\text { desa lainnya } \\
\text { SPBN tidak } \\
\text { tersedia } \\
\text { - Air bersih } \\
\text { sangat terbatas } \\
\text { - Akses jalan } \\
\text { kurag memadai }\end{array}$ \\
\hline 3 & $\begin{array}{l}\text { Lembaga } \\
\text { Pendukung }\end{array}$ & - & $\begin{array}{l}\text { - Belum terdapat } \\
\text { Kelompok } \\
\text { Usaha Bersama } \\
\text { (KUB) nelayan } \\
\text { - Belum } \\
\text { terbentuk } \\
\text { koperasi } \\
\text { nelayan } \\
\text { - Belum ada } \\
\text { lembaga } \\
\text { pelatihan/penyu } \\
\text { luhan perikanan } \\
\text { - Lembaga } \\
\text { keuangan } \\
\text { perbankan } \\
\text { masih terbatas } \\
\text { dan belum } \\
\text { tersebar }\end{array}$ \\
\hline
\end{tabular}

Sumber : Data Primer 2021, diolah

\section{Analisis SWOT Kawasan Minapolitan Satasabang}

Analisis SWOT dinarasikan dengan empat kategori dengan data yang telah diperoleh baik sekunder maupun data primer. Analisis ini telah banyak digunakan pada beberapa artikel dalam memberikan interpretasi realistis tentang kekuatan, kelemahan, kesempatan dan tantangan dengan latar belakan dan focus penelitian yang bervariasi, namun memiliki kesamaan dalam penelitian ini misalnya (Muhyidin et al., 2017) dengan penelitian Inovasi Pembangunan dan Pemberdayaan Kewilayahan menggunakan SWOT, (Salatan et al., 2018) yang meneliti Strategi Pemberdayaan Masyarakat Nelayan Soma Pajeko di Kec. Salibabu Kab. Kep. Talaud Sulawesi Utara, (Fuada et al., 2018) dengan penelitian Evaluasi Pemberdayaan Masyarakat Dalam Penanggulangan Gaki Dengan Metode SWOT di Kab. Wonosobo, selanjutnya Optimalisasi Pelaksanaan Program LPMK dalam Kota Pekanbaru yang menggunakan SWOT dalam artikel (Mar'aini, 2019), kemudian Strategi Pemberdayaan Masyarakat dalam Pengembangan Jiwa Kewirausahaan (Entrepreneurship) di Dusun Langkan, Desa Landih, Kec. Bangli, Kab. Bangli oleh (Suadnyana et al., 2019), (Tampubolon, 2020) melengkapi analisis SWOT dalam Strategi Pemberdayaan Masyarakat Pesisir di Kab. Kep. Meranti. Adapun hasil analisis SWOT dalam penelitian ini diukur dengan beberapa parameter subyektif penelitian untuk memberikan batasan dan penajaman dalam analisisnya.

Kategori Kekuatan, berdasarkan hasil pembahasan focus pada analisis pengembangan Kawasan Minapolitan Satasabang, dapat dilihat dalam tabel berikut :

Tabel 3. Kategori Kekuatan Kawasan Minapolitan Satasabang

\begin{tabular}{|c|c|}
\hline Pertanyaan & Respon \\
\hline $\begin{array}{l}\text { Adanya potensi } \quad \text { pengembangan } \\
\text { minapolitan }\end{array}$ & Ada \\
\hline Adanya hasil tangkapan nelayan & Ada \\
\hline Adanya nelayan yang teratur melaut & Ada \\
\hline Adanya rantai pasokan hasil tangkapan & Ada \\
\hline Adanya Transaksi Non Tunai & Tidak Ada \\
\hline
\end{tabular}




\begin{tabular}{ll}
\hline Adanya Lembaga keuangan perikanan & Tidak Ada \\
Adanya peningkatan pendapatan nelayan & Tidak tahu \\
Adanya respon terhadap satasabang & Ada \\
Adanya unit produksi & Tidak tahu \\
Adanya pengolahan produksi & Tidak tahu \\
Adanya pemasaran hasil produksi & Tidak tahu \\
Adanya Profil Desa & Ada \\
Adanya Sarpras pendukung & Tidak tahu \\
Adanya Program Prioritas Desa & Tidak Ada \\
Adanya produk Unggulan & Ada \\
\hline \multicolumn{2}{c}{ Sumber : Data Primer 2021, diolah }
\end{tabular}

Respon ditunjukan dengan tiga jawaban, apabila menjawab ada mendapat nilai 1 dengan nilai bobot 3 , apabila menjawab tidak tahu mendapat nilai 1 dengan nilai bobot 2 dan apabila menjawab tidak ada mendapat nilai 1 dengan nilai bobot 1 . Hasil dari pertanyaan tersebut kemudian diakumilasikan untuk memperoleh skor nilai bobot dari kategori kekuatan. Ukuran batas ditentukan dengan baseline yang merupakan nilai bobot tertinggi pada setiap pertanyaan dalam kategori ini. analisis kategori kekuatan menunjukan bahwa kondisi geografis memberikan potensi terhadap pengembangan Kawasan minapolitan Satasabang. Kondisi ini didukung dengan Hasil tangkapan yang mencapai rata-rata sebesar 670 kilogram dalam sekali melaut atau dalam satu bulan mencapai 12.730 kilogram, hasil tersebut diperoleh dari adanya Nelayan yang melaut. Namun dari sisi Rantai pasokan, masih memerlukan pembenahan, hal yang sama juga terjadi pada transaksi yang dilakukan oleh utamanya nelayan karena belum tersedianya Lembaga keuangan. Selanjutnya dari sisi Pendapatan meskipun menerima namun masih terdapat pembagian yang tidak standard yang cenderung ditentukan oleh pemilik modal. Respon pengembangan Kawasan Minapolitan ditanggapi dengan positif dengan memperhatikan ketersediaan Sarpras produksi, Sarpras pengolahan dan Sarpras pemasaran. Dari sisi respon perangkat desa telah ditunjukan dengan adanya potensi yang masih perlu ditingkatkan dalam pengelolaan Profil Desa karena terdapat ketidak seragaman dalam proses pengumpulan potensi yang dihasilkan nelayan yang perlu didukung dengan ketersediaan yang memadai terhadap Sarpras pendukung dan Program, sehingga pengembangan Kawasan Minapolitan Satasabang dengan unggulan produk perikanan dapat tercapai. Adapun kategori kekuatan seperti pada gambar berikut

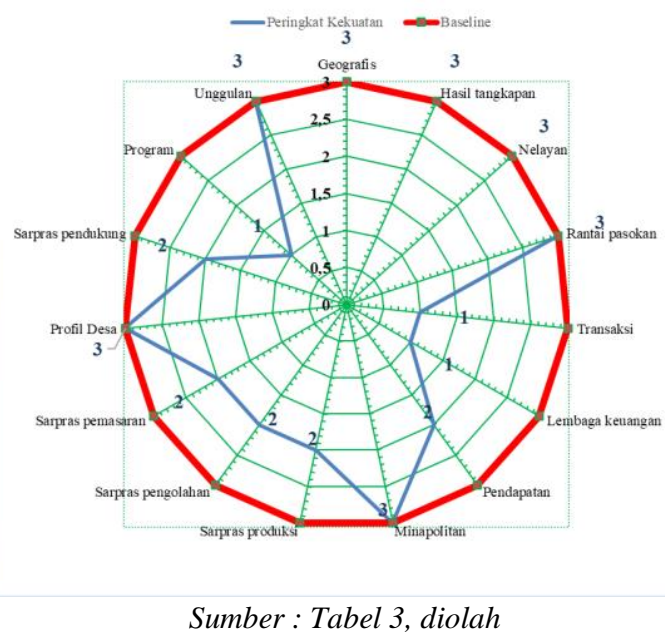

Gambar 2. Kurva Radar Kekuatan Kawasan Minapolitan Satasabang

Untuk memperoleh hasil pengukuran kuantitas dari kategori kekuatan dapat ditunjukan dengan bentuk kurva radar yang merupakan rangkuman dari pertanyataan pada tabel 1. Nilai bobot baseline sebesar 3 untuk setiap pertanyaan sedangkan respon dari hasil pengukuran tertera seperti dalam gambar. Hasil pengukuran dalam kurva radar menunjukan bahwa masih ada beberapa pertanyaan yang belum sejalan dengan batas baseline. Nilai hasil pengukuran kategori kekuatan terakumulasi sebanyak 34 poin dari total baseline sebanyak 45 poin, atau dapat dinyatakan sebesar $75,56 \%$ perbandingan antara hasil pengukuran dengan baseline

Dalam kategori kelemahan, menggunakan mekanisme yang sama seperti kategori kekuatan dalam proses pengukurannya. Adapun hasil pengukurannya seperti dalam tabel berikut Tabel 4. Kategori Kelemahan Kawasan Minapolitan Satasabang

\begin{tabular}{cc}
\hline Pertanyaan & Respon \\
\hline memiliki waktu melaut & Ada
\end{tabular}




\begin{tabular}{ll}
\hline kurang perlengkapan melaut & Tidak Tahu \\
Tidak memiliki pendidikan & Tidak Tahu \\
rendahnya daya tawar hasil & \\
tangkapan & Ada \\
memiliki citra pasar yang lemah & Ada \\
memiliki keterampilan pemasaran & \\
di bawah rata-rata & Ada \\
memiliki keuntungan di bawah & \\
standar & Ada \\
memiliki lini produk yang sempit & Ada \\
tidak dapat mengikuti perubahan & \\
strategi yang dibutuhkan & Tidak Tahu \\
terganggu dengan masalah internal & \\
$\begin{array}{l}\text { SDM } \\
\text { memiliki rekam jejak yang tidak }\end{array}$ & Ada \\
teratur dalam melaut & Tidak Tahu \\
Tidak maksimalnya di Penelitian \& & \\
$\begin{array}{l}\text { Pengembangan } \\
\text { memiliki biaya keseluruhan yang } \\
\text { tinggi }\end{array}$ & Ada \\
tidak memiliki infrastruktur yang & \\
siap & Tidak Tahu \\
\hline UMBER : DATA PRIMER 2021, DIOLAH & \\
&
\end{tabular}

Hasil pengukuran menujukan bahwa dalam proses Pengelolaan masih terdapat lini produk yang perlu dibenahi, ketersediaan Perlengkapan juga turut andil dalam upaya untuk meningkatkan hasil tangkapan, dari respon derajat Pendidikan ditemukan ada yang bahkan tidak sekolah menjadikan kelemahan dalam pengembangan Kawasan minapolitan Satasabang ini. Rendahnya Pendidikan turut mempengaruhi adanya daya tawar yang cenderung tidak mampu menjadi penentu dan semakin lebih menurun dengan adanya Citra Pasar yang hanya mampu memasarkan ikan segar. Hal ini juga tidak dapat ditekankan kepada para responden karena Ketrampilan yang dimiliki cukup terbatas sehingga berdampak pada Keuntungan yang diterima meski telah melaut dari pagi hari hingga sore hari selama 19 hari dalam satu bulan. Indicator yang menyumbang kelemahan adalah rendahnya Jalur Produk / Layanan yang dapat diakses oleh para nelayan, kecenderungan penetrasi dari Eksternalitas yang tinggi menjadikan sumbangan kelemahan, didukung dengan permasalahan
Internal yang dihadapi nelayan saat akan melaut dan pasca melaut. Rendahanya ketersediaan Data hasil tangkapan yang secara berkelanjutan menjadi kelemahan yang harus diperhatikan dalam pengembangan Kawasan Minapolitan, dengan melakukan Penelitian dan Pengembangan sesuai dengan kebutuhan yang dalam bentuk kajian sederhana namun implementatif, dari sisi peningkatan Keterampilan Pemasaran masih memerlukan intervensi dari stakeholder terkait dengan dukungan Fasilitas yang dapat diakses oleh para nelayan untuk mencapai tujuan pengembangan Kawasan satasabang.

Hasil pengukuran menunjukan bahwa skor bobot yang diperoleh mencapai $85,71 \%$ dengan perolehan nilai pengukuran sebesar 36 poin dari baseline yang ditentukan sebesar 42 poin. Dalam kategori ini semakin kecil kesenjangan antara hasil pengukuran dengan baseline maka akan semakin besar kelemahan yang perlu diantisipasi oleh berbagai pihak dan berlaku sebaliknya. Adapun kurva radar dapat dilihat pada gambar berikut

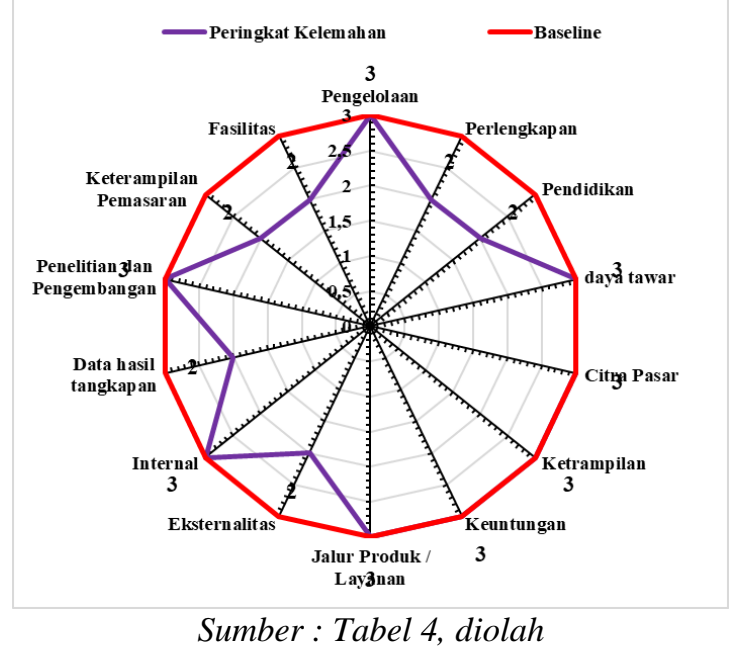

Gambar 3. Kurva Radar Kelemahan Kawasan Minapolitan Satasabang

Kategori Kesempatan yang dapat diidentifikasi dalam kajian pengembangan Kawasan minapolitan Satasabang ini terdapat sebanyak 11 pertanyatan yang kemudian direspon dengan jawaban ya, mungkin dan tidak. Satasabang memiliki 
potensi yang dapat dikembangkan menjadi Kawasan minapolitan meskipun dibutuhkan dukungan dari berbagai macam pendekatan baik dari sisi unit produksi, pengolahan, pemasaran maupun infratruktur serta sarana prasarana. Pengembangan Pasar baru yang tidak terbatas pada ikan segar memberikan kesempatan bagi stakeholder terkait untuk berpartisipasi. Hal ini dilakukan agar dapat terjadi peningkatan Produk / Layanan mulai dari hulu hingga hilir sehingga mampu memberikan kesempatan kepada nelayan dalam peningkatan pendapatan. Kesempatan untuk melakukan integrasi vertikal yang direncanakan dalam roadmap SIDa dapat digunakan untuk mengembangkan skala perdagangan luar daerah sebagai upaya untuk pengembangan pasar. Selain itu memiliki kesempatan dalam diversifikasi pasar yang berstrata sehingga semakin banyak pilihan yang dapat menambah daya saing produk. Adapun hasil respon dari kategori kesempatan seperti dalam tabel berikut

Tabel 5. Kategori Kesempatan Kawasan Minapolitan Satasabang

\begin{tabular}{|c|c|}
\hline Pertanyaan & Respon \\
\hline Ada potensi peningkatan hasil tangkapan & Mungkin \\
\hline $\begin{array}{l}\text { Ada pasar baru atau segmen pasar dan } \\
\text { diversifikasi produk selain ikan segar } \\
\text { dapat memperluas lini produk / layanan }\end{array}$ & Ya \\
\hline pasca melaut & $\mathrm{Ya}$ \\
\hline dapat melakukan diversifikasi pendapatan & \\
\hline $\begin{array}{l}\text { nelayan } \\
\text { dapat mengontrol aktivitas sumber atau } \\
\text { pasokan (integrasi vertikal) }\end{array}$ & Mungkin \\
\hline $\begin{array}{l}\text { Potensi pengembangan perdagangan } \\
\text { untuk membuka pasar luar daerah }\end{array}$ & $\mathrm{Ya}$ \\
\hline $\begin{array}{l}\text { Sinergi pengembangan kawasan } \\
\text { minapolitan antar stakeholder terbuka } \\
\text { luas }\end{array}$ & Mungkin \\
\hline $\begin{array}{l}\text { Pasar tumbuh lebih cepat dengan } \\
\text { diversifikasi }\end{array}$ & $\mathrm{Ya}$ \\
\hline Intervensi Roadmap SIDa & Ya \\
\hline $\begin{array}{l}\text { Dukungan regulasi dan program dari } \\
\text { stakeholder }\end{array}$ & Ya \\
\hline
\end{tabular}

Kesempatan proses ini dapat dilakukan dengan agenda terukur dalam Roadmap SIDa sehingga mampu menambah kecepatan pasar untuk tumbuh dan berkembang dalam Kawasan minapolitan. Adapun kurva radar hasil pengukuran kategori kesempatan terhadap baseline dapat dilihat pada gambar berikut

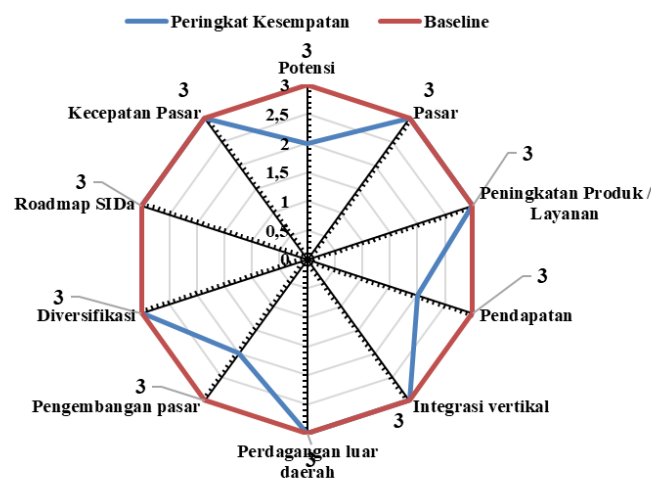

Sumber : Tabel 5, diolah

Gambar 4. Kurva Radar Kesempatan

Kawasan Minapolitan Satasabang

Hasil pengukuran dalam kurva radar menghasilkan skor respon sebesar 27 poin dari baseline sebesar 30 poin atau dapat disebutkan sebanyak 90\% kategori kesempatan memberikan hasil analisisnya terhadap akumulasi SWOT. Pada kategori kesempatan ini hasil yang diperoleh dari pengukuran respon berbanding lurus dengan total baseline yang ditentukan. Semakin tinggi hasil pengukuran terhadap respon maka akan semakin baik kesempatan yang dapat diperoleh dari focus penelitian ini.

Kategori keempat yaitu tantangan, menghasilkan 13 indikator berdasarkan respon dari data primer yang diperoleh, respon tersebut kemudian dianalisis dengan pengukuran. Adapun respon dari kategori tantangan dapat dilihat pada tabel berikut:

Tabel 6. Kategori Tantangan Kawasan Minapolitan Satasabang

\begin{tabular}{ll}
\hline Pertanyaan & Respon \\
\hline Dermaga labuh kapal kurang memadai & Ya \\
TPI yang tidak berfungsi optimal & Ya \\
Stasiun pengisian bahan bakar & \\
kapal/perahu & Ya \\
\hline
\end{tabular}




\begin{tabular}{ll}
\hline Air bersih sangat terbatas & Ya \\
Akses jalan kurag memadai & Ya \\
Belum terdapat Kelompok Usaha & \\
$\begin{array}{l}\text { Bersama (KUB) nelayan } \\
\text { Belum terbentuk koperasi nelayan }\end{array}$ & Ya \\
Belum ada lembaga pelatihan/ & \\
penyuluhan perikanan & Ya \\
$\begin{array}{l}\text { Toko distributor penyedia alat tangkap } \\
\text { di pelabuhan terbatas. }\end{array}$ & Ya \\
$\begin{array}{l}\text { Perusahaan pembekuan ikan yang ada } \\
\text { belum memadai }\end{array}$ & Ya \\
$\begin{array}{l}\text { Perubahan demografis berdampak } \\
\text { negatif terhadap bisnis }\end{array}$ & Mungkin \\
$\begin{array}{l}\text { Kesulitan untuk memasuki industri } \\
\text { pengolahan }\end{array}$ & Tidak \\
$\begin{array}{l}\text { Rendahnya Teknologi dapat mengubah } \\
\text { industri }\end{array}$ & Mungkin \\
\hline
\end{tabular}

Sarana Prasarana berupa dermaga yang belum memadai sebagai tempat berlabuh memberikan tantangan dalam pengembangan Kawasan Minapolitan Satasabang, termasuk ketersediaan TPI sebagai komponen yang digunakan nelayan dalam bertransaksi. Di samping itu perlengkapan nelayan masih terbatas baik dari sisi kuantitas bahan bakar maupun kuantitas stasiun bahan bakar. Kemudahan akses logistik nelayan juga memberikan tantangan bagi pengembangan Kawasan Agropolitan, selain itu infrastruktur Kawasan memerlukan perhatian khusus mengingat kondisi jalan yang kurang memadai. Organisasi ekonomi nelayan baik berupa KUB maupun koperasi menjadi kompnen penting yang dibutuhkan untuk kecepatan informasi dan transaksi nelayan dalam pengembangan hasil tangkapannya. Perlunya pelatihan/penyuluhan secara berkelanjutan dengan mengintervensi nelayan melalui pendekatan inovasi sederhana namun mampu menyelesaikan permasalahan baik teknis maupun non teknis menjadikan roadmap SIDa semakin dibutuhkan. Kemudahan akses terhadap pelengkap rantai pasokan yang dapat direspon sektor privat dan penanganan pasca hasil tangkapan merupakan upaya dalam mempercepat peningkatan produksi dalam Kawasan Satasabang ini. Dalam konteks demografi yang merupakan komponen utama saat melaut dapat menjadi tantangan apabila tidak ditangani dengan berkelanjutan. Selanjutnya industri pengolahan

Sebagai pendukung dari penanganan hasil tangkapan dengan pendekatan teknologi yang telah ada menjadi penting dalam pengembangan Kawasan Satasabang ini. Adapun kurva radar dapat dilihat pada gambar berikut

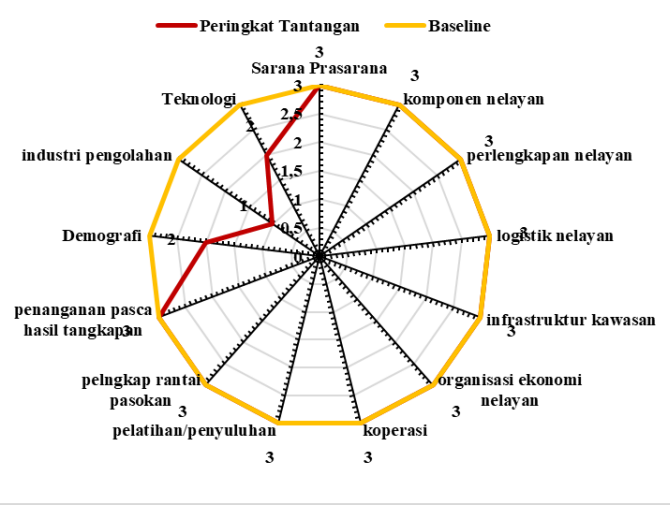

Sumber : Tabel 6, diolah

Gambar 5. Kurva Radar Tantangan

Kawasan Minapolitan Satasabang

Hasil pengukuran dalam kurva radar memperoleh skor respon sebesar 35 poin mendekati baseline yang mencapai skor 39 poin atau dapat diprosentasekan sebesar hampir $90 \%$.

Selanjutnya setelah melakukan pengukuran terhadap keempat kategori tersebut, tahap terakhir adalah mengakumulasikan keempat kategori untuk mengetahui hasil keseluruhan dari pengukuran respon berdasarkan masingmasing baseline ketegori. Dari hasil pengukuran terlihat bahwa akumulasi antara kekuatan dan kesempatan memperoleh skor sebanyak 61 poin, sedangkan akumulasi antara kelemahan dan tantangan memperoleh skor sebanyak 71 poin, terjadi selisih sebanyak 11 poin. Kondisi ini menunjukan bahwa pengembangan Kawasan Satasabang sebagai Kawasan minapolitan masih memerlukan strategi baik dalam meningkatkan produksi, produktivitas, dan kualitas produk kelautan dan perikanan; meningkatkan pendapatan nelayan, 
pembudidaya ikan, dan pengolah ikan yang adil dan merata; dan mengembangkan kawasan minapolitan sebagai pusat pertumbuhan ekonomi di daerah. Hasil akumulasi keempat kategori dapat dilihat pada tabel dan gambar berikut

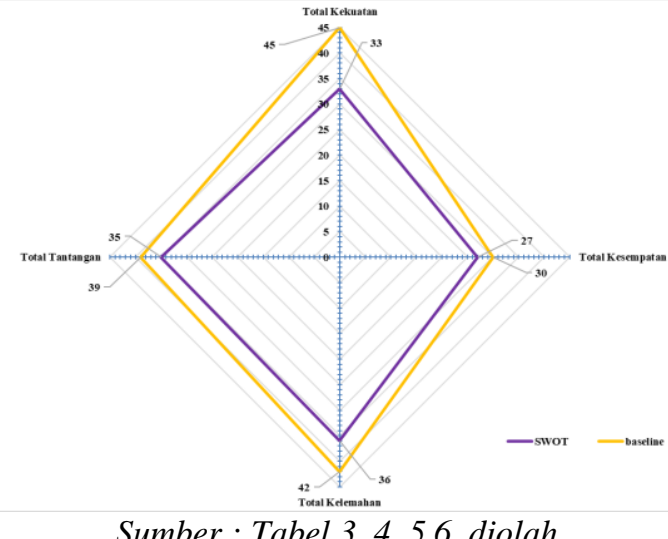

Gambar 6. Kurva Radar SWOT Kawasan Minapolitan Satasabang

Dalam gambar 6 memberikan penjelasan bahwa kategori kekuatan dan kesempatan masih membutuhkan upaya untuk meningkatkannya dilihat dari sumbu hasil pengukuran yang masih berada di dalam sumbu baseline, sedangkan untuk kelemahan dan tantangan sudah dalam posisi sumbu yang dapat ditingkatkan untuk menjadi lebih rendah atau menjauhi baseline yang ditetapkan. Adapun strategi yang dapat digunakan sebagai saran rekomendasi adalah mengembangkan rencana strategis dan taktis dalam roadmap SIDa untuk fokus menjadi Kawasan Minapolitan di Kabupaten Labuhanbatu dan menjalankan roadmap SIDa dengan seluruh stakeholder terkait; Menganalisis desain organisasi / fungsional untuk efisiensi dan efektivitas untuk memenuhi kebutuhan Kawasan Satasabang; mengembangkan strategi untuk menciptakan skala ekonomis untuk penawaran produk / layanan utama terhadap utamanya hasil tangkapan dan diversifikasi produk hasil tangkapan; mengembangkan strategi untuk membedakan produk / layanan, penjualan atau distribusi untuk menciptakan pasar yang dilindungi; menentukan apakah paten, hak cipta yang muncul akibat adanya inovasi yang dimanfaatkan oleh Kawasan Satasabang, baik yang berasal dari perangkat daerah, nelayan, perguruan tinggi maupun masyarakat yang berkontribusi dari luar Kawasan Satasabang; melakukan Audit Pemasaran dan Benchmark pesaing terkemuka untuk menentukan efisiensi dan efektivitas; mengembangkan dan mengelola proses ideasi dan inovasi formal; mengembangkan atau mendapatkan keterampilan teknis dari berbagai actor yang memiliki keahlian yang dapat dikontribusikan dalam pengembangan Kawasan Satasabang; mengembangkan strategi untuk meningkatkan skala ekonomi, margin keuntungan, dan efisiensi dengan pendekatan kelembagaan.

\section{KESIMPULAN}

Hasil identifikasi hasil perikanan yang diperoleh nelayan di lokus penelitian menunjukan adanya potensi hasil tangkapan yang melimpah, namun membutuhkan dukungan kelembagaan, infrastruktur, peningkatan kapasitas dan kemampuan nelayan. Hasil analisis komoditas unggulan yang dapat dikembangkan di Satasabang dengan pengukuran SWOT diperoleh skor 61 poin untuk total kekuatan dan kesempatan, sedangkan total kelemahan dan tantangan mencapai 71 poin, sehingga masih membutuhkan upaya yang lebih dalam mengembangkan Kawasan Satasabang menjadi Kawasan Minapolitan. Upaya pengembangan secara bertahap dapat melalui Roadmap SIDa Kabupaten Labuhanbatu tahun 2021-2026. Tujuh opsi strategi Kawasan Satasabang sebagai Kawasan yang menjadi agenda dalam Roadmap SIDa Kabupaten Labuhanbatu tahun 2021-2026 adalah Kembangkan dan jalankan rencana strategis dan taktis untuk fokus sebagai Kawasan minapolitan; Menganalisis desain organisasi / fungsional untuk efisiensi dan efektivitas; Kembangkan strategi untuk menciptakan 
skala ekonomis untuk penawaran produk / layanan utama; Kembangkan strategi untuk membedakan produk / layanan, penjualan atau distribusi untuk menciptakan pasar yang dilindungi; Tentukan dan harus dikembangkan kekayaan intelektual yang muncul dalam pengembangan Kawasan Satasabang; Lakukan Audit Pemasaran dan Benchmark pesaing terkemuka untuk menentukan efisiensi dan efektivitas; Kembangkan dan kelola proses ideasi dan inovasi formal; Kembangkan atau dapatkan keterampilan teknis; dan terakhir Kembangkan strategi untuk meningkatkan skala ekonomi, margin keuntungan dan efisiensi.

\section{UCAPAN TERIMA KASIH}

Ucapan terima kasih disampaikan kepada Kepala Badan Penelitian dan Pengembangan Kabupaten Labuhanbatu yang telah memberikan kesempatan dalam penulisan artikel ini.

\section{DAFTAR PUSTAKA}

Erdi Suroso, Wisnu Satyajaya (2016). Kajian Keputusan Komoditas Unggulan Pengembangan Agroindustri Perdesaan di Kabupaten Tulang Bawang. Jurnal Inovasi Pembangunan, Volume 04 No. 122 36).

Ridwan Saifuddin (2020), Pemanfaatan Teknologi Informasi Dalam Peningkatan Pendapatan Asli Daerah . Jurnal Imovasi Pembangunan, Volume 08 No. 2 (183).

Adhihapsari, W., Semedi, B., \& Mahmudi, M. (2014). Perencanaan Pengembangan Wilayah Kawasan Minapolitan Budidaya di Gandusari Kabupaten Blitar. J-Pal, vol.5(7-14), 7-14.

Agustine, A. D. (2016). Implementasi Program Pengembangan Kawasan Minapolitan Perikanan Budidaya Di Rajapurbawa Kabupaten Banjarnegara. PUBLISIA (Jurnal Ilmu Administrasi
Publik), 1(2), 43-50.

Ambasari, L., Gandasasmita, K., \& Sudadi, U. (2013). Strategi Pengembangan Kawasan Perikanan Budidaya Di Kabupaten Lampung Timur. Globe, 15(2), 137-145.

Benzaghta, M. A., Elwalda, A., Mousa, M., Erkan, I., \& Rahman, M. (2021). SWOT analysis applications: An integrative literature review. Journal of Global Business Insights, 6(1), 5573. https://doi.org/10.5038/26406489.6.1.1148

Cahya, D. L., \& Mareza, M. D. (2013). Konsep Pengembangan Kawasan Minapolitan Ketapang Kabupaten Lampung Selatan. Planesa, 4(2), 4652.

D, F., Ikawati, \& Amri, E. (2018). Strategi Pengembangan Kawasan Minapolitan Di Kecamatan Pamboang Kabupaten Majene Dalam Konsep Pengembangan Wilayah. Plano Madani: Jurnal Perencanaan Wilayah Dan Kota, 7(1), 37-45.

Dewi, L., \& Asparini, P. S. (2018). Analisis

Kawasan Minapolitan Sebagai

Destinasi Wisata. National

Conference of Creative Industry,

September, 5-6.

https://doi.org/10.30813/ncci.v0i0.11 98

Edrus, I. N. (2015). Analisis Pengembangan Kawasan Minapolitan Kota Bengkulu Key Policies of the Area Development for Pond Culture Based- Minapolitan of Bengkulu City. Jurnal Kebijakan Perikanan Indonesia, 7(2), 79-92.

Erlina, M. D., \& Manadiyanto, M. (2012). Strategi Pengembangan Kawasan Minapolitan Berbasis Usaha Pegaraman. Jurnal Kebijakan Sosial Ekonomi Kelautan Dan Perikanan, 2(1), https://doi.org/10.15578/jksekp.v2i1. 9259

Febriyanti, R. E. (2013). Kontribusi Pengembangan Kawasan Minapolitan Kampung Lele Terhadap Pendapatan 
Petani Lele Di Desa Tegalrejo Sawit Boyolali. Economics Development Analysis Journal, 2(4), 396-408. https://doi.org/10.15294/edaj.v2i4.32 08

Fuada, N., Martiyana, C., Asturiningtyas, I. P., \& Riyanto, S. (2018). Evaluasi Pemberdayaan Masyarakat Dalam Penanggulangan Gaki Dengan Metode SWOT Di Kabupaten Wonosobo. Media Gizi Mikro Indonesia, 9(1), 3750.

https://doi.org/10.22435/mgmi.v9i1.6 29

Handayani, W., Setyono, J. S., Sophianingrum, M., \& Kusharsanto, Z. S. (2012). Kajian Pengembangan Sistem Inovasi Daerah (SIDa) Kota Semarang. Jurnal Riptek, 6(2), 1-16.

Hikmah, H., \& Purnomo, A. H. (2012). Kesiapan Dan Strategi Kebijakan Pengembangan Minapolitan Berbasis Perikanan Budidaya. Jurnal Kebijakan Sosial Ekonomi Kelautan Dan Perikanan, 2(1), 27. https://doi.org/10.15578/jksekp.v2i1. 9261

Ismiatun, I. (2015). Pengembangan Sistem Inovasi Dalam Perspektif Peningkatan Daya Saing Daerah Dengan Pendekatan System Dynamics. Jurnal Ilmu Sosial Dan Ilmu Politik Universitas Tribhuwana Tunggadewi, 4(2), 42437.

Karepesina, M., Abrahamsz, J., \& Lopulalan, Y. (2019). Status Keberlanjutan Dan Strategi Pengembangan Kawasan Minapolitan Perikanan Budidaya Di Kabupaten Seram Bagian Barat. Jurnal PAPALELE, 3(2), 61-71.

Kuhu, R. A., Wuisang, C. E. V., \& Mononimbar, W. (2019). Analisis Kawasan Minapolitan Danau Tondano Di Kabupaten Minahasa. Jurnal Spasial, 6(2), 159-168.

Kurniati, A. C., Babarsari, J., Tunggal, C., \& Ruang, P. (2020). Kajian penetapan lokasi prioritas kawasan minapolitan di kabupaten bantul. Matra, 1(1), 12-
22.

Lune, H. \& Berg, B. L. (2017). Qualitative Research Methods for the Social Sciences (9th Edition). In Pearson Education Limited.

Mar'aini. (2019). Strategi Optimalisasi Pelaksanaan Program LPMK dalam Kota Pekanbaru. Jurnal Menara Ilmu, XIII(11), 44-52.

Maulana, U., \& Nurhadi. (2016). Strategi Pengembangan Kawasan Dalam Mendukung Peningkatan Daya Saing Antar Kecamatan Di Kabupaten Kulon Progo. Geomedia, 14(2), 55-64. Muhyidin, M., Sumpena, D., \& Aziz, A. (2017). Pemberdayaan Masyarakat Melalui Program Inovasi Pembangunan dan Pemberdayaan Kewilayahan. ... Masyarakat Islam, 2(September), 59-79. http://jurnal.fdk.uinsgd.ac.id/index.ph $\mathrm{p} /$ tamkin/article/view/761

Narutomo, T. (2014). Program Penguatan Sistem Inovasi Daerah (SIDa) Sebagai Exit Strategy Program Nasional Pemberdayaan Masyarakat (PNPM). Jurnal Bina Praja, 06(02), 143-156. https://doi.org/10.21787/jbp.06.2014. 143-156

Nursan, M., Nabilah, S., Made, N., \& Sari, W. (2020). Potensi Dan Strategi Pengembangan Kawasan Minapolitan Kertasari Kabupaten Sumbawa Barat. Jurnal Ilmiah Membangun Desa Dan Pertanian (JIMDP).

Onibala, H., Kepel, R. C., \& Sinjal, H. J. (2019). Development of minapolitan area in Bitung City, Indonesia. Aquatic Science \& Management, 6(1), 1. https://doi.org/10.35800/jasm.6.1.201 8.24809

Risandewi, T. (2017). Implementasi dan Capaian SIDa di Kabupaten Blora Tahun 2012-2015. Matra Pembaruan, $1(3)$, 153-164. https://doi.org/10.21787/mp.1.3.2017. 153-164

Salatan, S., Manoppo, V. E. N., \& Darwisito, S. (2018). Strategi Pemberdayaan Masyarakat Nelayan 
Soma Pajeko Di Kecamatan Salibabu Kabupaten Kepulauan Talaud Sulawesi Utara. Jurnal Sosial Ekonomi Kelautan Dan Perikanan, 13(1), 87. https://doi.org/10.15578/jsekp.v13i1. 6851

Shara, A. R. I. D. (2019). Analisis Kawasan Minapolitan Di Desa Pengambengan, Kecamatan Negara, Kabupaten Jembrana-Bali. Media Komunikasi Geografi, $19(2), \quad 194$. https://doi.org/10.23887/mkg.v19i2.1 6562

Suadnyana, I. W. S., Putra, I. G. S. A., \& Sarjana, I. M. (2019). Strategi Pemberdayaan Masyarakat dalam Pengembangan Jiwa Kewirausahaan (Entrepreneurship) di Dusun Langkan, Desa Landih, Kecamatan Bangli, Kabupaten Bangli. Jurnal Agribisnis Dan Agrowisata (Journal of Agribusiness and Agritourism), 8(1), 80.

https://doi.org/10.24843/jaa.2019.v08 .i01.p09

Surbakti, A. P. L., Tondobala, L., \& Supardjo, S. (2019). Analisis Tingkat Pelayanan Infrastrruktur Pendudkung Kawasan Minapolitan Petasia Di Kabupaten Morowali Utara. Jurnal Spasial, 6(1), 1-13.

Suresti, Amna Dinata, Uyung Gatot S. Hellyward, James Wati, R. (2017). Pemetaan Tingkat Kematangan Sistem Inovasi Daerah (SIDa) Peternakan Di Kab.Lima Puluh Kota Sumatera Barat. Journal of Economic, Business and Accounting (COSTING), 1(1), 35-42.

Tampubolon, D. (2020). Strategi Pemberdayaan Masyarakat Pesisir di Kabupaten Kepulauan Meranti. Sorot, 8(2), 153-161.

Zain, M. A., \& Febrianty, I. (2018). Strategi Pengembangan Usaha Budidaya Ikan Di Kawasan Minapolitan Kabupaten Banjar Dalam Menghadapi Persaingan Masyarakat Ekonomi Asean. Prosiding Seminar Nasional
Lingkungan Lahan Basah, 3(2), 535539.

\section{Peraturan-peraturan}

Undang-Undang Nomor 31 Tahun 2004 tentang Perikanan sebagaimana telah diubah dengan Undang-Undang Nomor 45 Tahun 2009;

Undang-Undang Nomor 16 Tahun 2006 tentang Sistem Penyuluhan Pertanian, Perikanan dan Kehutanan;

Undang-undang Nomor 26 Tahun 2007 tentang Penataan Ruang;

Undang-Undang Nomor 27 Tahun 2007 tentang Pengelolaan Wilayah Pesisir dan Pulau-Pulau Kecil;

Undang-Undang nomor 17 Tahun 2007 tentang Perencanaan Pembangunan Jangka Panjang Tahun 2005-2025;

Peraturan Pemerintah Nomor 54 Tahun 2002 tentang Usaha Perikanan;

Peraturan Menteri Kelautan dan Perikanan Nomor PER.06/MEN/2010 tentang Rencana Strategis Kementerian Kelautan dan Perikanan;

Peraturan Menteri Kelautan dan Perikanan Nomor PER.18/MEN/2012 tentang Pedoman Penyusunan Rencana Induk Pengembangan Kawasan Minapolitan; Peraturan Menteri Kelautan dan Perikanan Nomor PER.12/MEN/2010 tentang Minapolitan;

Peraturan Menteri Kelautan dan Perikanan Nomor 39/2011 tentang Penetapan Kawasan Minapolitan;

Keputusan Menteri Perikanan dan Kelautan No. 18 Tahun 2011 Tentang Pedoman Umum Minapolitan. 
